\title{
Number of fragments, margin status and thermal artifacts of conized specimens from LLETZ surgery to treat cervical intraepithelial neoplasia
}

\author{
Número de fragmentos, status das margens e artefatos térmicos de peças conizadas \\ de cirurgia com alças de ondas de alta frequência no tratamento da neoplasia \\ intraepitelial cervical
}

\author{
Dulcimary Dias Bittencourt', Rita Maira Zanine", Ana Martins Sebastião'I", Nabiha Saadi Tahalv , Neila Góis Speckv , Julisa \\ Chamorro Lascasas Ribaltavi
}

Universidade Federal de São Paulo (Unifesp), São Paulo, Brazil

\begin{abstract}
Postgraduate Student Gynecological Diseases Prevention Center (Núcleo de Prevenção de Doenças Ginecológicas, Nuprev), Universidade Federal de São Paulo (Unifesp), São Paulo, Brazil. "MD, PhD. Adjunct Professor, Department of Obstetrics and Gynecology, Universidade Federal do Paraná (UFPR), Curitiba, Paraná, Brazil. "'MD, PhD. Pathologist and Titular Professor, Centro Universidade Positivo (Unicenp), Curitiba, Paraná, Brazil.

"MD, PhD. Assistant Professor and Head of Electrical Surgery Group, Gynecological Diseases Prevention Center (Núcleo de Prevenção de Doenças Ginecológicas, Nuprev), Universidade Federal de São Paulo (Unifesp), São Paulo, Brazil. ${ }^{\vee} M D$, PhD. Affiliated Professor and Head of Lower Gynecological Tract Sector, Gynecological Diseases Prevention Center (Núcleo de Prevenção de Doenças Ginecológicas, Nuprev), Universidade Federal de São Paulo (Unifesp), São Paulo, Brazil.

"MD, PhD. Associate Professor and Head of Gynecological Diseases Prevention Center (Núcleo de Prevenção de Doenças Ginecológicas, Nuprev), Department of Gynecology, Universidade Federal de São Paulo (Unifesp), São Paulo, Brazil.
\end{abstract}

\section{KEY WORDS:}

Conization.

Cervical intraepithelial neoplasia.

Colposcopy.

Electrocoagulation

Women.

\section{PALAVRAS-CHAVE:}

Conização.

Neoplasia intraepitelial cervical.

Colposcopia.

Eletrocoagulação.

Mulheres.

\begin{abstract}
CONTEXT AND OBJECTIVE: Large loop excision of the transformation zone (LLETZ) is a nontraumatic cut and coagulation method with several advantages, but it induces thermal artifacts in the cut region. The aim here was to assess the correlations of age, number of fragments, lesion grade and degree of thermal artifacts with margin quality in conized specimens from LLETZ for cervical intraepithelial neoplasia (CIN). DESIGN AND SETTING: Cross-sectional study at Universidade Federal de São Paulo (Unifesp).

METHODS: The records and histopathology findings of 118 women who underwent LLETZ between 1999 and 2007 were reviewed. Age, number of fragments, lesion grade, degree of thermal artifacts and margin quality were assessed.

RESULTS: The patients' mean age was 27.14 years; $63.6 \%$ had been diagnosed with CIN II and $36.4 \%$ with CIN III. The lesion was removed as a single fragment in $79.6 \%$ of the cases. The margins were free from intraepithelial neoplasia in $85.6 \%$ and compromised in the endocervical margin in 6.8\%. Fragment damage due to artifacts occurred in 2.5\%. Severe artifacts occurred in 22.8\%. Women aged 30 years or over presented more cases of CIN III $(P<0.0004)$. Neoplastic compromising of surgical margins and severe artifacts occurred more often in cases in which two or more fragments were removed, and in patients aged 30 years or over.

CONCLUSION: CIN III in women aged 30 or over, when removed in two or more fragments during LLETZ, presented a greater number of compromised margins and greater severity of thermal artifacts.
\end{abstract}

\section{RESUMO}

CONTEXTO E OBJETIVO: Cirurgia de alta frequência (CAF) é um método não traumático de corte e coagulação com muitas vantagens, porém induz a artefatos térmicos na região do corte. O objetivo foi avaliar a relação entre idade, número de fragmentos, grau da lesão e grau de artefatos térmicos e a qualidade das margens das peças cirúrgicas resultantes da CAF para neoplasia intraepitelial cervical (NIC).

TIPO DE ESTUDO E LOCAL: Estudo transversal na Universidade Federal de São Paulo (Unifesp).

MÉTODOS: Foram revisados prontuários e laudos histopatológicos de 118 mulheres que foram submetidas a conização por cirurgia de alta frequência no período de 1999 a 2007. Idade, número de fragmentos, grau da lesão, grau de artefatos térmicos e qualidade das margens foram avaliados.

RESULTADOS: A idade média das pacientes foi de 27,14 anos; $63,6 \%$ tinham diagnóstico de NIC II e 36,4\% de NIC III. A lesão foi retirada com um fragmento em $79,6 \%$. As margens estavam livres de neoplasia em $85,6 \%$ e comprometidas na margem endocervical em 6,8\%. Fragmentos prejudicados por artefatos ocorreram em 2,5\%. Artefatos de grau severo ocorreram em 22,8\%. Mulheres com idade igual ou superior a 30 anos apresentaram mais casos de NIC III (P<0,0004). O comprometimento neoplásico de margens cirúrgicas e artefatos de grau severo ocorreram mais vezes nos casos em que foram retirados dois ou mais fragmentos e em pacientes com idade igual ou superior a 30 anos.

CONCLUSÃO: NIC III em mulheres com idade superior a 30 anos, quando retiradas em dois ou mais fragmentos na CAF, apresentaram maior número de margens comprometidas e grau severo de artefatos térmicos. 


\section{INTRODUCTION}

Electrosurgery, sometimes referred to as radiosurgeryor diathermy, was initially used in 1926 by Harvey Cushing and William T. Bovi. In 1981, René Cartier proposed using small low-voltage high dielectric loops to biopsy and excise the transformation zone, requiring several passes of the loop. In 1989, Walter Prendiville used large loops, thereby removing the transformation zone as only one or two fragments. This treatment method is known as large loop excision of the transformation zone (LLETZ) or the loop electrosurgical excision procedure (LEEP). ${ }^{1-4}$

LLETZ is a nontraumatic cut and coagulation method with several advantages over cold knife conization, such as lower cost and shorter surgical procedure and recovery time for the patient. ${ }^{1,5}$ In contrast with destructive methods for lesion treatment, LLETZ enables collection of material for anatomopathological evaluation. ${ }^{6,7}$ However, despite all of its advantages, LLETZ induces thermal artifacts in the cut region. Their magnitude varies according to the surgeon's ability, the number of fragments removed and the equipment used. If these fragments are not properly identified, they may cause problems for anatomopathological interpretation..$^{8-10}$

\section{OBJECTIVE}

The aim of this study was to evaluate the number of fragments, margin status and thermal artifacts of conized specimens obtained by means of LLETZ, in cases in which a single professional with experience of the technique performed the procedure.

\section{METHODS}

We conducted a retrospective study using a convenience sample of medical records from 118 patients with high-grade cervical intraepithelial neoplasia (CIN) who underwent LLETZ between 1999 and 2007. This study was approved by the Ethics Committee of Hospital São Paulo, Universidade Federal de São Paulo (Unifesp).

The surgical procedures were performed in a private clinic by a single professional with considerable experience of the technique. The surgical method consisted of removing the transformation zone of the cervix, using a loop electrode measuring 2.0 x $0.8 \mathrm{~cm}$ connected to a LLETZ PLUS machine (Zinnanti Surgical Instruments, Chatsworth, California, United States).

The patients were placed in the gynecological position and the neutral plate of the machine was positioned. The cervix was visible after placement of the speculum connected to a biological vapor vacuum. 3\% acetic acid was applied, and the cervical lesion was viewed under a $16 \mathrm{x}$ colposcope. Lugol's solution was applied to the cervix to mark out the cut area better. Local anesthesia was applied in the four quadrants of the cervix (12, 3,6 and 9 o'clock) with an infiltrate of $0.5 \mathrm{ml}$ of lidocaine at $2 \%$ with a vasoconstrictor. Looking through the colposcope, the surgeon activated the machine via a pedal and removed the piece using the chosen loop, which was passed across the area in a fast, continuous, firm movement, with voltage calibrated to 36 watts for cutting. Depending on the size of the lesion, it was sometimes necessary to remove more than one fragment. After excision, a 40 watt, $3 \mathrm{~mm}$ spherical electrode was applied to induce coagulation, followed by application of Monsel's hyperchlorite paste to achieve hemostasis, and finally placement of a vaginal tampon. The material collected was then sent for anatomopathological analysis.

For this study, the thin sections were reviewed by two pathologists, one of them evaluated half of the sample. All 118 samples were diagnosed as severe intraepithelial neoplasia and were evaluated to determine the margin quality, degree of thermal artifacts and number of fragments. Margins considered compromised were those with cell abnormalities compatible with human papillomavirus (HPV), CIN I, CIN II or CIN III.

The degree of thermal artifacts was graded as mild, moderate or severe. Mild artifacts were characterized by a thin layer of thermal coagulation in the margin. In the mucosa, the thermal action was slight, with or without highlighting of the epithelium. This caused no problem in making the final diagnosis of the degree of compromised margin. Moderate artifacts consisted of a layer of more noticeable thermal coagulation, visible in all histological thin sections. The thermal artifacts extended and altered the shape and size of structures such as glands, cells and nuclei. Complete highlighting of the epithelium of the mucosa was observed. Making a final diagnosis was still possible. Severe artifacts consisted of the presence of extensive coagulative necrosis zones, wrinkling of the tissue, swelling and blurring of cell details. In this situation, making a final diagnosis of compromised margin was impossible. The statistical analysis used the chi-square $\left(\chi^{2}\right)$ test. Statistical significance was accepted when $\mathrm{P}<0.05$.

\section{RESULTS}

The patients ages were between 17 and 55 years of age, with an average of 27.1 years.

Severity of the histopathological lesion: Out of the 118 cases, 75 (63.6\%) were grade 2 cervical intraepithelial neoplasia (CIN II) and the other 43 (36.4\%) were grade 3 cervical intraepithelial neoplasia (CIN III).

Number of surgical fragments: In 94 cases (79.7\%), a single fragment was removed, and in 24 cases $(20.3 \%)$, two or more fragments were removed.

Compromising of the surgical margins: In 101 cases (85.5\%), the margins were free; in eight cases (6.8\%), the endocervical margins were compromised; in two cases $(1.7 \%)$, the ectocervical margins were compromised; in four cases $(3.4 \%)$, both margins were compromised; and in three cases (2.5\%), the 
margins were damaged by artifacts. In none of the cases was the margin damaged by fragmentation.

Degree of thermal artifacts: In 55 cases (46.6\%), the grade was mild; in 36 cases (30.5\%), the grade was moderate; and in 27 cases $(22.9 \%)$, the artifact grade was severe (Table 1 ).

Analysis of the association between age and lesion severity showed that there was a greater percentage of CIN II cases among the women less than 30 years of age. Among the women aged 30 years or over $(\mathrm{P}=0.004)$, CIN III occurred in 21 cases $(75.8 \%)$ (Table 2).

Among the women aged up to 30 years, excision was done as a single fragment in $82.7 \%$ and as two fragments in $17.3 \%$. After the age of 30 years, these proportions were $73 \%$ and $27 \%$ respectively.

Analysis of the relationship between surgical margin compromising and age showed that the margins were predominantly free in the two age groups considered. However, there were more cases of compromised margins in the upper age group: $21.6 \%$ versus only $7.5 \%$.

Table 1. Distribution of 118 patients according to lesion grade, number of fragments, margin quality and degree of thermal artifacts

\begin{tabular}{lcc} 
Histopathological grade of the cervical lesion & $\mathbf{n}$ & $\%$ \\
$\quad$ Cervical intraepithelial neoplasia II & 75 & 63.6 \\
$\quad$ Cervical intraepithelial neoplasia III & 43 & 36.4 \\
$\begin{array}{l}\text { Number of surgical fragments } \\
\text { One fragment }\end{array}$ & 94 & 79.7 \\
$\quad$ Two or more fragments & 24 & 20.3 \\
Surgical margins & & \\
Free & 101 & 85.6 \\
Endocervical compromised & 8 & 6.8 \\
Ectocervical compromised & 2 & 1.7 \\
Both compromised & 4 & 3.4 \\
Damaged by thermal artifacts & 3 & 2.5 \\
Damaged by fragmentation & 0 & 0 \\
Thermal artifacts & & \\
Mild & 55 & 46.6 \\
Moderate & 36 & 30.5 \\
Severe & 27 & 22.9 \\
\hline
\end{tabular}

Table 2. Relationship between age and histopathological grade of the lesion in 118 women with cervical squamous intraepithelial neoplasia grades II and III, who underwent large loop excision of the transformation zone (LLETZ); $\mathrm{P}=0.004$ (chi-square test)

\begin{tabular}{|c|c|c|c|c|c|c|}
\hline \multirow{3}{*}{ Age } & \multicolumn{4}{|c|}{ Lesion grade } & \multirow{2}{*}{\multicolumn{2}{|c|}{ Total }} \\
\hline & \multicolumn{2}{|c|}{$\begin{array}{c}\text { Cervical } \\
\text { intraepithelial } \\
\text { neoplasia II }\end{array}$} & \multicolumn{2}{|c|}{$\begin{array}{c}\text { Cervical } \\
\text { intraepithelial } \\
\text { neoplasia III }\end{array}$} & & \\
\hline & $n$ & $\%$ & $n$ & $\%$ & $\mathrm{n}$ & $\%$ \\
\hline$<30$ & 59 & 72.8 & 22 & 27.2 & 81 & 100.0 \\
\hline$\geq 30$ & 16 & 43.2 & 21 & 57.8 & 37 & 100.0 \\
\hline Total & 75 & 100.0 & 43 & 100.0 & 118 & 100.0 \\
\hline
\end{tabular}

Analysis of the relationship between age and occurrence of thermal artifacts showed that $32.4 \%$ of the cases in the older women group presented severe artifacts, while this proportion was $18.5 \%$ in the younger group.

Evaluation of the relationship between the number of surgical fragments and the grade of histopathological legion showed that there was no difference in distribution between the variables. Similarly, there was no noticeable relationship between the distribution of thermal artifacts and the number of fragments.

The surgical margins were free from compromise in the majority of cases, regardless of the number of surgical fragments. However, in the group with two or more fragments, $25 \%$ of the margins were compromised, whereas in the group with only one fragment, $8.5 \%$ were compromised. In the group with two or more fragments, $4.2 \%$ of the margins were damaged by artifacts, compared with $2.1 \%$ in the group with a single fragment.

The distribution of the degree of thermal artifacts was similar in the two groups defined by surgical margin compromising, such that $100 \%$ of the margins damaged by artifacts presented severe-grade artifacts.

The distribution of CIN II and CIN III cases in relation to surgical margin compromising showed that $64.2 \%$ of the cases in the compromised margin group were CIN III, versus $35.7 \%$ with CIN II in the same group. $66.6 \%$ of the cases with margins damaged by artifacts were in the CIN III group, versus $33.3 \%$ in the CIN II group. Similar distribution of different artifact grades was registered in the two CIN groups.

\section{DISCUSSION}

As seen in other studies, the severity of the intraepithelial lesions worsened with greater age of the women. ${ }^{11}$ In $79.6 \%$ of the cases, the lesion was removed as a single fragment, and this was similar to what was reported by other authors, who found that $60 \%$ to $92 \%$ of the cases resulted in single fragments. ${ }^{12-14}$ The number of fragments removed was greater in the group aged 30 years and over, and this fragmentation increased the uncertainty of the diagnosis. The success interpreted in a high number of margins was probably due to the fact that the fragments were removed in a single pass, thereby facilitating orientation. Regarding margin compromising, $11.9 \%$ of the margins were compromised by lesions, i.e. similar to values seen in other studies..$^{12,15,16}$

In this study, the endocervical margin was the most compromised, as was seen by other authors. ${ }^{17-20}$ Analysis on the relationship between age and margin compromising showed a positive association, which has also been supported by other authors. ${ }^{17,21}$ This study presented more cases of compromised margins when the lesion grade was higher.

Despite the compromised margins in the LLETZ specimens, only a small number of patients will have residual and recurrent 
disease at follow-up. Thus, they do not require immediate retreatment, but their conservative follow-up should include colposcopic and cytological assessments. ${ }^{22,23}$

The relationship between the intensity of artifacts and patient age group showed that the older group had twice as many severe artifacts as shown by the younger group, although without statistical significance. This suggests the possibility that the cervical structure is more fibrous in older women, thereby constituting a risk factor for thermal artifacts, since such structures would retard the cutting speed. Similarly, another study showing this through evaluating the degree of thermal artifacts in different age groups was conducted by Taha et al. ${ }^{24}$ On the other hand, in a study by Montz et al., ${ }^{8}$ artifact grade was not affected by patient age.

In this study, the severity of thermal artifacts did not present any relationship with the number of fragments. Nevertheless, many other authors have found that the thermal artifacts are milder with lower fragmentation. The quantity of artifacts might be related to the surgeon's skill. In the cases cited here, there was no damage from fragmentation, which may be attributable to the fact that the procedure was carried out by a professional experienced in this technique, and that the loop used was large: $2.0 \times 0.8 \mathrm{~cm}$. Here, $2.5 \%$ of the margins were damaged by artifacts, which is similar to the proportion found by other authors. ${ }^{14,25,26}$

The literature presents many references to compromised margins, with percentages ranging from $0.0 \%$ to $30.5 \%$, due to artifacts or fragmentation, thereby adversely affecting the histopathological interpretation. The highest rate (30.5\%) was observed by Mathevet et al. ${ }^{27}$ in a study in which the equipment was not effective, and the physicians had various levels of experience with the procedure. Boardman et al. ${ }^{28}$ observed that $28 \%$ of their cases shown adverse effects on interpretation, with procedures conducted by physicians under training.

\section{CONCLUSION}

We concluded that when two or more fragments are removed during LLETZ in treatment for NIC III, in women aged 30 or over, a greater number of compromised margins is observed and also greater severity of thermal artifacts in these fragments.

\section{REFERENCES}

1. Sperli AE, Freitas JOG, Fischler R. Rinofima: tratamento com equipamento de alta frequência (radiofrequência) [Rhinophyma: treatment with high-frequency equipment (radiofrequency)]. Rev Bras Cir Plást. 2009;24(4):504-8.

2. Cartier R, Cartier I, Caldas IS. Colposcopia prática. 3a ed. São Paulo: Roca; 1994

3. Prendiville W, Cullimore J, Norman S. Large loop excision of the transformation zone (LLETZ). A new method of management for women with cervical intraepithelial neoplasia. Br J Obstet Gynaecol. 1989;96(9):1054-60.
4. Apgar BS, Wright TC Jr, Pfenninger JL. Loop electrosurgical excision for CIN. Am Fam Physician. 1992;46(2):505-20.

5. Dores GB. HPV na genitália feminina. Manual e guia prático de cirurgia de alta frequência. São Paulo: Multigraf Editora Ltda; 1994.

6. de Carbezón RH, Sala CV, Gomis SS, Lliso AR, Bellvert CG. Evaluation of cervical dysplasiatreatmentbylargeloopexcision ofthetransformation zone (LLETZ). Does completeness of excision determine outcome? Eur J Obstet Gynecol Reprod Biol. 1998;78(1):83-9.

7. Dobbs SP, Asmussen T, Nunns D, et al. Does histological incomplete excision of cervical intraepithelial neoplasia following large loop excision of transformation zone increase recurrence rates? A six-year cytological follow-up. BJOG. 2000;107(10):1298-301.

8. Montz FJ, Holscheneider CH, Thompson LD. Large-loop excision of the transformation zone: effect on the pathologic interpretation of resection margins. Obstet Gynecol. 1993;81(6):976-82.

9. Naumann RW, Bell MC, Alvarez RD, et al. LLETZ is an acceptable alternative to diagnostic cold-knife conization. Gynecol Oncol. 1994;55(2):224-8.

10. Duggan BD, Felix JC, Muderspach LI, et al. Cold-knife conization versus conization by the loop electrosurgical excision procedure: a randomized, prospective study. Am J Obstet Gynecol. 1999;180(2 Pt 1):276-82

11. Moore KN, Bannon RJ, Lanneau GS, et al. Cervical dysplasia among women over 35 years of age. Am J Obstet Gynecol. 2008;199(5):471.e1-5.

12. Chappatte OA, Byrne DL, Raju KS, Nayagan M, Kenney A. Histological differences between colposcopic-directed biopsy and loop excision of the transformation zone (LETZ): a cause for concern. Gynecol Oncol. 1991;43(1):46-50.

13. Oyesanya OA, Amerasinghe CN, Manning EA. Outpatient excision management of cervical intraepithelial neoplasia. A prospective, randomized comparison between loop diathermy excision and laser excisional conization. Am J Obstet Gynecol. 1993;168(2):485-8.

14. Gardeil F, Barry-Walsh C, Prendiville W, Clinch J, Turner MJ. Persistent intraepithelial neoplasia after excision for cervical intraepithelial neoplasia grade III. Obstet Gynecol. 1997;89 (3):419-22.

15. Howe DT, Vicenti AC. Is large loop excision of the transformation zone (LLETZ) more accurate than colposcopically directed punch biopsy in the diagnosis of cervical intraepithelial neoplasia? $\mathrm{Br} J$ Obstet Gynaecol. 1991;98(6):588-91.

16. Mor-Yoseh S, Lopes A, Pearson S, Monaghan JM. Loop diathermy cone biopsy. Obstet Gynecol. 1990;75(5):884-6.

17. Flannelly $G$, Bolger B, Fawzi H, De Lopes AB, Monaghan JM. Follow up after LLETZ: could schedules be modified according to risk of recurrence? BJOG. 2001;108(10):1025-30.

18. Ramchandani SM, Houck KL, Hernandez E, Gaughan JP. Predicting persistent \recurrent disease in the cervix after excisional biopsy. MedGenMed. 2007;9(2):24

19. Rema P, Suchetha S, Thara S, et al. Effectiveness and safety of loop electrosurgical excision procedure in a low-resource setting. Int J Gynaecol Obstet. 2008;103(2):105-10. 
20. Bozanović T, Ljubic A, Momcilov P, et al. Cold-knife conization versus the loop electrosurgical excision procedure for treatment cervical dysplasia. Eur J Gynaecol Oncol. 2008;29(1):83-5.

21. Shin JW, Rho HS, Park CY. Factors influencing the choice between cold knife conization and loop electrosurgical excisional procedure for the treatment of cervical intraepithelial neoplasia. J Obstet Gynaecol Res. 2009;35(1):126-30

22. Jakus S, Edmonds P, Dunton C, King SA. Margin status and excision of cervical intraepithelial neoplasia: a review. Obstet Gynecol Surv. 2000;55(8):520-7.

23. Zaitoun AM, McKee G, Coppen MJ, Thomas SM, Wilson PO. Completeness of excision and follow-up cytology in patients treated with loop excision biopsy. J Clin Pathol. 2000;53(3):191-6.

24. Taha NSA, Focchi J, Ribalta JCL, et al. Avaliação do grau e da extensão das alterações térmicas produzidas pela cirurgia de alta freqüência no colo uterino [Evaluation of the intesity and the extensión of termal alterations produced by high frequency surgery in the uterine cervix]. Rev Bras Ginecol Obstet. 2001;23(1):47-51.

25. Spitzer M, Chernys AE, Seltzer VL. The use of large-loop excision of the transformation zone in an inner-city population. Obstet Gynecol. 1993;82(5):731-5.

26. Luesley DM, Cullimore J, Redman CW, et al. Loop diathermy excision of the cervical transformation zone in patients with abnormal cervical smears. BMJ. 1990;300(6741):1690-3.

27. Mathevet $P$, DargentD, Roy M, Beau G. A randomized prospective study comparing three techniques of conization: cold knife, laser, and LEEP. Gynecol Oncol. 1994;54(2):175-9.

28. Boardman LA, Steinhoff MM, Shackelton R, Weitzen S, Crowthers $\mathrm{L}$. A randomized trial of the Fischer cone biopsy excisor and loop electrosurgical excision procedure. Obstet Gynecol. 2004;104(4):745-50.

This paper was presented as a poster at the $15^{\text {th }}$ Brazilian Congress of Genitoscopy (October 6-10, 2010, in Porto Alegre) and as a master's degree dissertation

Sources of funding: None

Conflict of interest: None

Date of first submission: October 3, 2010

Last received: July 26, 2011

Accepted: August 1, 2011

\section{Address for correspondence:}

Dulcimary Dias Bittencourt

Rua Martin Afonso, 1.817

Bigorrilho - Curitiba (PR) - Brasil

CEP 80730-030

Tel. (+55 41) 35681430

Cel. (+55 41) 99878034

E-mail: dulcimarybittencourt@bol.com.br 